\title{
Growth Dynamics of Value-Added Tax Revenue in Ghana
}

\author{
Francis Kwaw Andoh', Nehemiah E. Osoro², Eliab Luvanda²
}

ABSTRACT The introduction of the value-added tax (VAT) to replace the sales tax in 1995 was one of the key
policy steps undertaken by the government of Ghana (GoG) to further deepen and sustain the
efficiency of Ghana's tax system to boost tax revenue. This study uses quarterly data from 2000 to
2014 and employs dynamic ordinary least squares (DOLS) and Divisia Index approaches to examine
the growth of Ghana's VAT revenues and how this growth is affected by discretionary tax measures.
On the whole, the study finds that all of the measures of VAT revenue (total VAT, domestic VAT, and
import VAT) have experienced some growth. Growth in total VAT and import VAT is driven strongly
by growth in the base, while that of the domestic VAT is driven by both discretionary tax measures
and the tax base. Discretionary tax measures are found to have a depressive effect on both total VAT
and import VAT revenue growth.

KEY WORDS: $\quad$ value-added tax, consumption tax, tax collection and fiscal policy

JEL Classification: $\quad \mathrm{H} 25, \mathrm{H} 26, \mathrm{E} 62$

${ }^{1}$ School of Economics, University of Cape Coast, Ghana, ${ }^{2}$ Dept. of Economics, University of Dar es Salaam, Tanzania

\section{Background}

Value-added tax (VAT) has emerged as the most significant fiscal tool in both developed and developing economies. It has been described as a "breath-taking tax development" (Ebrill, Keen, \& Summers, 2001) and the most significant event in the evolution of tax structures in the last half of the $20^{\text {th }}$ century (Cnossen, 1991). Currently, more than 164 countries worldwide have adopted VAT. Approximately two-thirds of leastdeveloped countries have a VAT (Annacondia \& van der Corput, 2012), and all of the 54 countries in Africa, except for six, levy a VAT (Crowe Horwarth International, 2016). As key strengths, VAT is believed to be broad based, avoiding cascading taxes (tax on another

Correspondence concerning this article should be addressed to: Francis Kwaw Andoh, School of Economics, University of Cape Coast, Ghana. E-mail: fandoh@ucc.edu.gh tax), thereby checking distortions and over taxation. It is also considered to have an inherent self-checking mechanism, hence the tendency to improve tax compliance and minimize the occurrence of tax avoidance, evasion and fraud. In view of the above qualities, VAT is said to have greater potential to raise a substantial amount of revenue even at moderately low rates and for countries that are even in their early stages of development (World Bank, 1991). It has also been argued that VAT revenue tends to be more stable over the economic cycle (Auerbach, 2010; Ebeke \& Ehrhart, 2012).

However, critics argue that gains from VAT are questionable, especially in sub-Saharan Africa (SSA) due partly to the existence of a large informal sector. Moreover, it is argued that in developing countries, there exists weak tax administrative capacity; hence, it is difficult to address gross abuse associated with exemptions, zero-rated goods and tax credit refunds, 
which have always been inherent in the structure and operation of VAT (Emran \& Stiglitz, 2005). Furthermore, since the prices of some VAT goods can react more strongly to macroeconomic fluctuations, VAT revenue might be less stable (Fricke, Süssmuth, \& Süssmuth, 2014).

Studies on tax revenue growth abound. Recent ones include Sobel and Holcombe (1996) Bruce, Fox, and Tuttle (2006) for the US; Cotton (2012) for Trinidad and Tobago; Koester and Priesmeier (2012) for Germany; Kargbo and Egwaikhide (2012) for Sierra Leone; Wolswijk (2009) for the Netherlands; Belinga, Benedek, de Mooij and Norregaard (2014) for OECD countries; Fricke et al. (2014) for Latin American countries; Wawire (2003) for Kenya; Choudhry (1979) for the United States, United Kingdom, Malaysia and Kenya; and Kusi (1998) for Ghana. However, none of the studies paid detailed attention to VAT revenue growth. Twerefou, Fumey, Assibey and Asmah (2010), which is the study closest to ours, estimated the buoyancy and elasticity of a number of tax handles, including VAT for Ghana for the period of 1970-2007. The VAT was reintroduced in 1998; hence, at the time of the study, VAT had been in operation for only seven years. In light of this data limitation, the study merged sales tax and VAT into one variable. Obviously, the results could be more reflective of sales tax than VAT. Moreover, the focus of the study was to compare the tax buoyancy of the pre-economic reform era (before 1984) and the postreform era (i.e. after 1984).

In view of the centrality of the VAT to Ghana's fiscal consolidation efforts, examining its growth dynamics is imperative. Our key contribution is that we use exclusive and extended data on VAT revenues and apply the recently developed two-step (2S) regression approach of error correction model to estimate the long- and short-term VAT buoyancy. We also employ the superior Divisia Index technique to isolate the elasticity coefficients from the buoyancy coefficients. The study also goes further to estimate the buoyancy and elasticity of the disaggregated VAT components (domestic VAT and import VAT) while at the same time, examining the asymmetric responses for each component. These dimensions are very useful for monitoring tax revenue performance and government fiscal planning.

\subsection{VAT in Ghana}

The VAT was first introduced in Ghana in January 1995 (actual collection started in March 1995). However, after three and half months (June 1995), the VAT was suspended due to public protests resulting in several deaths. It was reintroduced in January 1998. The introduction of the VAT was in line with the recommendations of the then ongoing IMF's Enhanced Structural Adjustment Facility (ESAF), which specifically emphasized a tax reform centered on a "broadbased consumption tax, notably a VAT". This step was undertaken to encourage developing economies to move away from income taxation and its associated distortions and toward consumption taxation. Prior to the introduction of the VAT, Ghana's indirect tax regime was principally based on sales tax, which was administered by the Customs, Excise and Preventive Service (CEPS), and a services tax, administered by the Internal Revenue Service (IRS).

By design, the sales tax was levied only on goods and collected as a single-stage tax at the factory gate or at the point of importation, whereas the services tax was charged on hotels and restaurants (Hotels and Restaurants Customers Tax), advertisements (Advertisement Tax), sports betting (Betting Tax) and some entertainment (Entertainment Tax). As limitations, the sales tax excluded the retail and service sectors from the base of indirect taxation. This system undermined the buoyancy of the revenue system (Terkper, 1994a). In addition, sales tax provided exemptions for large numbers of supplies and end users, thereby distorting and eroding the revenue base of the tax system. Together, both the sales and services taxes were limited in scope and very complex because of the differentiated and multiple rates regime (which ranged between 10 percent and 15 percent), as well as the gamut of exemptions provided under the regime. Eventually, it became clear that the administration of these differentiated sales taxes encouraged tax misapplication, evasion and avoidance since these taxes could not meet the revenue targets (Terkper, 1994a; Osei \& Quartey, 2005). The above issues implicitly defined the principal goal of Ghana's VAT, particularly to address the fundamental problems of a distorted indirect tax regime, specifically the sales and services tax regimes and the bottlenecks exhibited by an ineffective administrative machinery (Terkper, 1994a). It 

register for VAT. The VAT on imports paid by a freight forwarding or shipping or clearing agent on behalf of an importer is an input tax that can be reclaimed by the importer and not the agent. This principle also applies to the VAT paid on any other services on behalf of the importer. However, when the agent is charged directly for a service, and the tax invoice is in his or her name, he or she is entitled to recover the VAT as an input tax but must also account for VAT in full on the services that he or she invoices to the importer (Ghana Revenue Authority, 2018).

Ghana's VAT is based on the destination principle, meaning that VAT is paid on all taxable supplies at the point of consumption, regardless of the country of production. Under the destination type, exports do not attract VAT, but imports do unless the item is an exempt supply. Appendix 1 provides a list of exempt goods and the year of exemption. Notable among the exempt goods are basic foodstuffs, medicines and pharmaceutical products, newspapers and books, water, electricity, public transportation, feed, seed, fertilizer, agricultural implements, petroleum products, and handicrafts. The invoice-credit VAT system of Ghana's VAT allows registered traders to automatically offset the tax paid on inputs against the taxes on output, with the difference paid to the tax authorities. When the amount of input VAT deductible exceeds the output tax, the tax authority (in this case the GRA) pays the difference. However, the latter case rarely occurs given that the output tax is based on value added. This system applies to both import VAT and domestic VAT on the basis that the inputs were used wholly, exclusively and necessarily in the course of the business (The Parliament of of Republic of Ghana, 2017).

\subsection{Dynamics of Tax Revenues in Ghana}

In broad terms, there are four categories of taxes in Ghana. They are taxes on income and property, taxes on domestic goods and services, international trade taxes and value-added tax. With the exception of the VAT, the other three categories have been operational in Ghana since independence. Prior to 1998 (before the reintroduction of VAT), taxes on international trade constituted the largest contribution to tax revenue in Ghana, followed by taxes on domestic goods and services and then taxes on income and property. Specifically, taxes on international trade contributed on average 38.8 percent to total tax revenue for the period of 1980-93 and 32.1 percent between 1996 and 1998. Taxes on domestic goods and services contributed on average 28.5 percent and 24.4 percent over the same period, respectively, and taxes on income and property contributed approximately 21.3 percent and 27.5 percent for the periods of $1980-93$ and 1996-98, respectively (Osei \& Quartey, 2005). However, the introduction of VAT introduced some twists into the relative contributions of the tax components. Income and property taxes became the major sources of tax revenue, contributing approximately 24.5 percent to total tax revenue in 1999, but their contribution increased steadily to 27.1 percent by 2002 . VAT placed second, contributing approximately 21.9 percent of total tax revenue in 1999 . This amount increased to 22.3 percent in 2002. International trade taxes, once the largest major component of tax revenue, placed third with 20.9 percent in 1999 and 19.3 percent in 2002. Taxes on goods and services contributed 14.9 percent of total tax revenue in 1999; but their contribution dropped to 10.5 percent in 2001 and subsequently increased to 14.0 percent in 2002 (Osei \& Quartey, 2005).

Over the last one and half decades, VAT has emerged as the largest contributor to total tax revenue, contributing on average approximately 28 percent of the total tax revenue -- almost twice the contribution of pay as you earn (PAYE) (14.1 percent) and approximately 17 times that of self-employed tax (1.58 percent). Import duties, which are the next largest contributor after VAT, account for 17.76 percent of total tax revenue, while company and PAYE contribute approximately 16.46 percent and 14.1 percent, respectively (Andoh, 2017). Figure 1 shows the contribution of VAT from 2001 to 2014 .

Generally, VAT revenue performance (based on VAT productivity and VAT collection efficiency) in African countries is, on average, lower than in other regions of the world, whether in the Middle East, the Western Hemisphere, Asia and the Pacific, or the European Union (WoldeMariam, 2010). Even then, Ghana's performance relative to other lower middleincome countries is not the best (see Table 1).

More than a decade into the VAT operation, Ghana is still ranked among the lowest performing countries in Africa in terms of tax-to-GDP ratio. Table 2 shows the trends in the tax-to-GDP ratio for Ghana from 


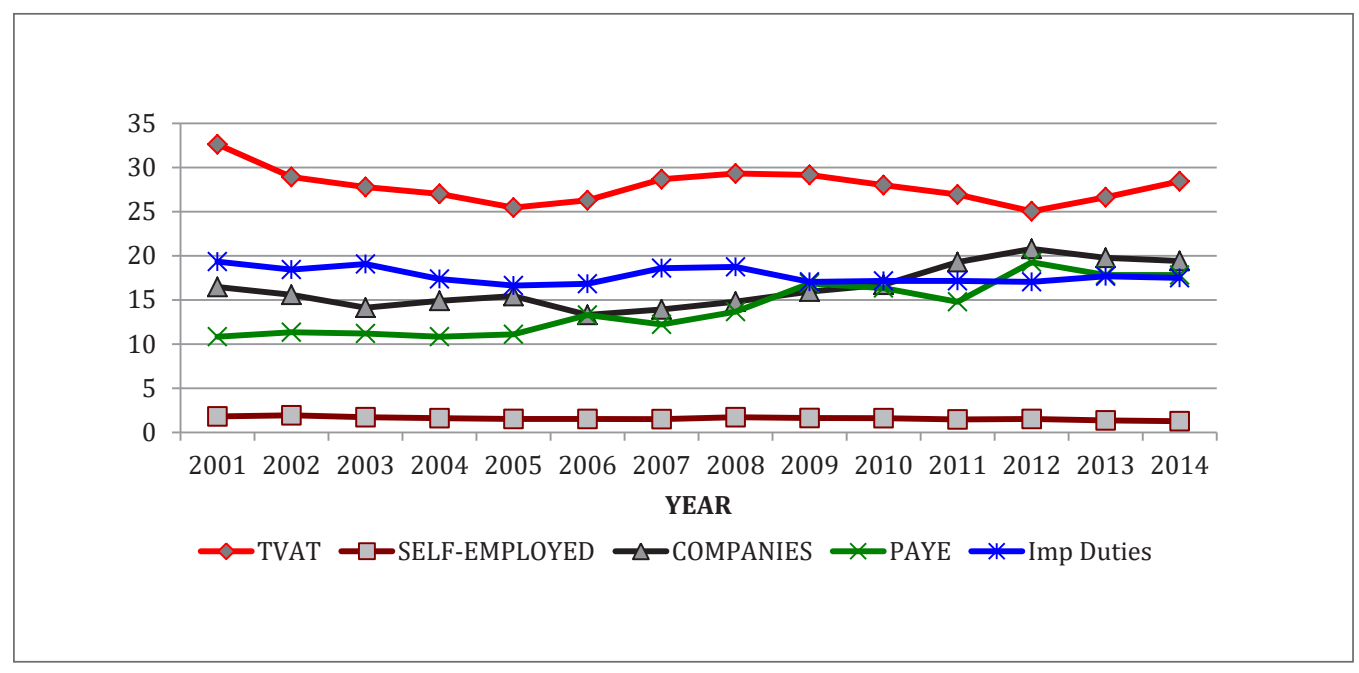

Figure 1. Contribution of VAT to Tax Revenue Compared to Other Taxes

Table 1. VAT Rates and Performance Among Selected Lower Middle Income Countries in Africa

\begin{tabular}{|c|c|c|c|c|c|c|}
\hline COUNTRY & $\begin{array}{c}\text { Year VAT } \\
\text { introduced }\end{array}$ & Standard rate & $\begin{array}{c}\text { VAT } \\
\text { C-efficiency }\end{array}$ & $\begin{array}{c}\text { VAT } \\
\text { productivity }\end{array}$ & $\begin{array}{c}\text { VAT (\% of tax } \\
\text { revenue) }\end{array}$ & Year of data \\
\hline Cape Verde & 2004 & 15.0 & 0.65 & 0.53 & 37.0 & 2006 \\
\hline Morocco & 1995 & 14.0 & 0.52 & 0.39 & 31.4 & 2006 \\
\hline Tunisia & 1998 & 18.0 & 0.50 & 0.30 & 24.3 & 2009 \\
\hline Ghana & 1998 & $15^{* *}$ & 0.39 & 0.27 & 30.1 & 2010 \\
\hline Kenya & 1990 & 16.0 & 0.35 & 0.39 & 28.7 & 2010 \\
\hline Cameroon & 1999 & 19.5 & 0.30 & 0.24 & 37.1 & 2006 \\
\hline Cote d'Ivoire & 1960 & 18.0 & 0.11 & 0.09 & 8.4 & 2010 \\
\hline
\end{tabular}

Source: Adapted from "Mobilizing VAT revenues in African countries" by Cnossen (2015). International Tax Public Finance, 22(6), 1077-1108. Retrieved from http://doi.org/10.1007/s10797-015-9348-1.

Note:

** Ghana has revised the standard rate on four occasions: 10\% in 1998, $12.5 \%$ in May 2000; 15 \% in Sept 2004; and 17.5 \% in January 2015.

Ranking is performed in a descending order based on VAT C efficiency

2006 to 2015, compared to other countries in the same lower middle-income bracket.

The tax-GDP ratio of Ghana has consistently remained at less than 18 percent, which is lower than the average for the developing world and even the average for Africa (Osei \& Quartey, 2005; World Bank, 2014; Bank of Ghana, 2014). These developments, therefore, cast some doubt about the revenue growth performance of the much-celebrated VAT, thereby rendering a thorough analysis very crucial. 
Table 2. Total Tax as a Percentage of GDP in Selected Lower Middle Income Countries in Africa from 2006 to 2016

\begin{tabular}{lccccccccccc}
\hline & \multicolumn{1}{c}{ YEAR } \\
\cline { 2 - 5 } & $\mathbf{2 0 0 6}$ & $\mathbf{2 0 0 7}$ & $\mathbf{2 0 0 8}$ & $\mathbf{2 0 0 9}$ & $\mathbf{2 0 1 0}$ & $\mathbf{2 0 1 1}$ & $\mathbf{2 0 1 2}$ & $\mathbf{2 0 1 3}$ & $\mathbf{2 0 1 4}$ & $\mathbf{2 0 1 5}$ & $\mathbf{2 0 0 6 -}$ \\
\hline Tunisia & 24.3 & 25.2 & 26.8 & 26.6 & 27.2 & 29.1 & 29.1 & 29.8 & 30.9 & 30.3 & 27.93 \\
Morocco & 25.4 & 29.7 & 30.2 & 26.9 & 27.7 & 28.5 & 29.5 & 28.1 & 27 & 26.1 & 25.1 \\
Cape Verde & 21.1 & 21.3 & 21.7 & 18.7 & 18.8 & 19.9 & 18.2 & 18.1 & 17.4 & 19.2 & 19.44 \\
Kenya & 17.2 & 17.9 & 18.7 & 18 & 17.7 & 18.4 & 17.7 & 17.8 & 19 & 18.4 & 18.08 \\
Africa & 16.6 & 17.2 & 17.7 & 17.1 & 17.2 & 17.8 & 18.1 & 18.5 & 18.8 & 19.1 & 17.81 \\
Cote d'Ivoire & 16.2 & 17.1 & 16.9 & 16.8 & 16.5 & 15.3 & 17.7 & 17.6 & 16.9 & 17.6 & 16.86 \\
Cameroon & 14 & 14.8 & 14.8 & 15 & 14 & 14.8 & 15.3 & 15.8 & 16.1 & 16.4 & 15.1 \\
Ghana & 13.1 & 13.2 & 12.7 & 13.1 & 13.2 & 14.5 & 14.8 & 13.6 & 15.0 & 15.0 & 13.82 \\
\hline
\end{tabular}

Source: Adapted from "Revenue Statistics in Africa" by OECD (2016). Retrieved from http://dx.doi.org/10.1787/9789264253308-en-fr Note:

Countries are ranked by authors in descending order based on the observed information in the table. Income classification is based on the World Bank classification: https://blogs.worldbank.org/opendata/new-country-classifications-2016

\section{Overview of Fiscal Development and Growth Performance}

Ghana's fiscal position continues to deteriorate. Figure 2 shows Ghana’s fiscal deficit from 1996 to 2016.

Although the economy registered surpluses in the mid-1980s, the deficit resurfaced in 1992 and has persisted ever since, except in 1994 and 1995 when there were surpluses of 2.8 percent and 1.7 percent of GDP, respectively (Alagidede, Baah-Boateng, \& Nketiah-Amposah, 2013). The deficit decreased from 8.5 percent in 2000 to 2.4 percent in 2005 . It , however, worsened, particularly over the subsequent years. It increased from 7.8 percent of GDP in 2006 to to 11.5 percent in $2008,10.0$ percent in $2013,11.8$ percent in 2014 and 10.3 percent in 2016. Ghana's debt was consequently considered to be unsustainable, thus compelling the country to request an Extended Credit Facility (ECF) from the IMF (IMF, 2015; World Bank, 2014; Republic of Ghana, 2017). While unrestrained public expenditure is believed to have contributed to this persistent deficit, weaker nonoil tax collection is considered to be largely responsible (Amo-Yartey, 2014).
The available statistics show that Ghana's economy has experienced some steady economic growth over the past decade. Real GDP grew from approximately 3.8 percent in 1994 to 5.8 percent in 2005 and subsequently to 6.2 percent in 2006 until it peaked at approximately 15 percent in 2011 (following the commercial production of oil), thus becoming one of the fastest growing economies in the world during this year. Between 1991 and 2013, the economy's average annual growth rate of 5.8 percent was higher relative to 3.7 percent in SSA. Per capita GDP stood at $\$ 439$ in 1991; however, it increased to $\$ 502$ in 2005, \$930 in 2006, \$1,099 in 2007 and \$1,858 in 2013 (Aryeetey \& Baah-Boateng, 2015; World Bank, 2014). As a result of the impressive growth performance, poverty fell from approximately 51 percent in 1991 to 39 percent in 2001 and further to 28.5 percent in 2005 (African Development Bank [AfDB], 2012; 2014). Consumption expenditures have also increased over the years. Based on Adam Smith's ability-to-pay principle of taxation (Kendrick, 1939), therefore, these developments should be reflected in increased tax revenues. 


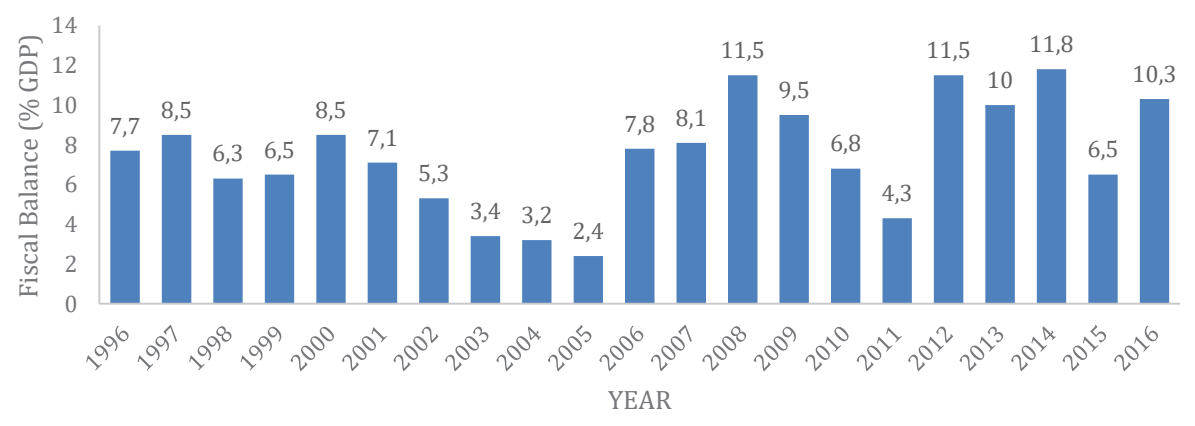

Figure 2. Ghana's Fiscal Deficit from 1996 to 2016

Source: Adapted from "Tax reform and revenue productivity in Ghana" by Kusi (1998), Available at https://opendocs.ids. ac.uk/opendocs/handle/123456789/2210

"Annual reports" by Bank of Ghana (several series) Available at https://www.bog.gov.gh/statistics/publication/annual-report

\subsection{The Concepts of Buoyancy and Elasticity}

Tax revenue growth performance is measured by two concepts: tax elasticity and tax buoyancy. Tax buoyancy is a measure of the total degree of responsiveness of tax revenue to both changes in the national income (national tax base) and discretionary changes in tax rates, tax rules, and tax administration. Tax elasticity, in contrast, measures the automatic response of tax revenue to changes in national income (or tax base) when the revenue effects of discretionary tax measures are removed (Bilquees, 2004; Osoro, 1993). Desirably, a good tax regime is expected to be both buoyant and elastic, i.e., yield coefficient greater than unity, indicating that the tax can potentially improve the fiscal balance through the revenue side of the budget. If changes in discretionary tax policy were revenue enhancing, the buoyancy coefficient would be greater than the elasticity coefficient. However, more preferably, the elasticity coefficient should be greater than the buoyancy coefficient to imply that the VAT regime will generate revenue automatically in response to growth in the tax base. In such a situation, tax authorities will not have to resort to frequent changes in tax policies and
VAT rates to increase the revenue yield. Such practices have often led to fierce protests in Ghana.

Tax buoyancy and elasticity can vary between the short and long term. Whereas the long-term responses measure the effect of economic growth on long-term fiscal sustainability, the short term captures the volatility (or the stability) of tax revenues and provides an indication of the extent to which the tax regime can be used as an automatic stabilizer. If the long-term coefficient is greater than unity, it indicates that more rapid growth of the economy (or tax base) will reduce the fiscal deficit ratio through improved revenue. Conversely, if the short-term coefficient exceeds one, it means that the tax system is highly variable, but at the same time, it could function as a good automatic stabilizer and vice versa (Belinga et al., 2014).

\section{Methodology}

In the tax literature, the standard econometric model for the empirical estimation of tax buoyancy is obtained by regressing the log of tax revenues on the log of the relevant tax base without controls (Belinga et al., 
2014; Dudine \& Jalles, 2017; Kargbo \& Egwaikhide, 2012; Kusi, 1998; Mansfield, 1972; Osoro, 1993; Sobel \& Holcombe, 1996; Twerefou, et al., 2010; Wawire, 2000; Wolswijk 2009). Thus, the baseline empirical model is specified in equation $(1)^{1}$.

$\ln R_{t}=\alpha+\beta \ln \mathrm{Y}_{t}+\mu_{t}$

where $\ln R_{t}$ is $\log$ of the tax revenue at time $t$, and $\ln \mathrm{Y}_{t}$ is the $\log$ of tax base at time $t$. The parameter $\beta$ is the tax buoyancy coefficient, while $\mu_{t}$ is the stochastic error term. Since the variables are in logs, $\beta$ is interpreted as elasticity or buoyancy, depending on whether tax revenue data are adjusted for changes in discretionary policy or not.

However, equation (1) might suffer from specification bias because important variables that affect VAT revenues are omitted from the model. It has been argued that VAT is more likely to perform better with improved tax administration capacity. Therefore, in line with the literature, GDP per capita (a measure of economic development) is used as a proxy for tax administration capacity and efficiency (Adam, Bevan, \& Chambas, 2001; Khattry \& Rao, 2002; Keen \& Lockwood, 2010). GDP per capita is therefore expected to be correlated positively with VAT buoyancy. The economic structure of the economy has also been implicated in many tax performance studies. As argued by Piggott and Whalley (2001) and Emran and Stiglitz (2005), VAT becomes inferior to tariffs in the presence of a large informal sector. The rationale is that the informal sector is extremely difficult to tax because almost all of the economic activities in the informal sector are in the underground economy. Therefore, an economy with a significantly large informal sector is more likely to experience poor tax performance. As in the empirical literature, the share of agriculture in GDP is used as a proxy for the size of the informal economy.

Equation (1) is, therefore, modified to capture the control variables:

$\ln R_{t}=\alpha+\beta \ln \mathrm{Y}_{t}+\varpi N_{t}+\mu_{t}$

where $N_{t}$ is a vector of control variables (in this case, $\log$ of GDP per capita and agriculture share of GDP). The variables $\ln R_{t}, \ln \mathrm{Y}_{t}$, and $\beta$ were defined earlier.

\subsection{Empirical Strategy}

The two-step (2S) regression approach proposed by Sobel and Holcombe (1996) and used by Bruce et al. (2006), Wolswijk (2009) and Koester and Priesmeier (2012) is adapted to estimate equation (2). The first step involves estimating a long-term model, which requires cointegrated relationships. The second step is to obtain the short-term dynamics of tax revenue responses through an error correction model (ECM). The first-step regression is estimated using the dynamic ordinary least squares (DOLS), an estimator developed by Saikkonen (1991) and Stock and Watson (1993) and appropriate for modeling long-term and cointegrated relationships. The advantage of DOLS over ordinary least squares (OLS) is that it addresses any potential endogeneity among regressors by augmenting the model with leads and lags of the first differences of the regressor (Bruce et al., 2006; Masih \& Masih, 2001). Moreover, Monte Carlo evidence on DOLS proved that the estimator is superior, especially with small samples (Stock \& Watson, 1993), compared to alternative long-term estimators, such as Engle and Granger (1987) and Phillips and Hansen (1990). In terms of policy, the lags and leads of the regressor are not of interest to this study.

The long-run buoyancy model for VAT is specified as:

$\ln R_{t}=\alpha_{t}+\sum_{n=1}^{N} \beta_{t, n} \ln \mathrm{X}_{n, j}+\sum_{g=-j}^{j} \lambda_{t, n} \Delta \mathrm{X}_{n, t+j}+\varpi \Delta N_{t}+\mu_{t}$

where $\ln R_{t}$ is the $\log$ is the observed tax revenue, $\ln \mathrm{X}_{n, j}$ is the log of the tax base, and $\Delta \mathrm{X}_{n}$, is the first dif-

ference of the tax base; hence, $\sum_{g=-j}^{j} \lambda_{t, n} \Delta \mathrm{X}_{n, t+j}$ shows the $j$

lags and leads of the first difference of the tax base. Due to the smaller sample, we limit the number of lags to one and the leads to one. The term $\mu_{t}$ is the stochastic error term, while the parameters $\lambda_{t, n}$ and $\beta_{t, n}$ are the coefficients of the leads and lags of the first difference of the tax base and the log of the tax base, respectively. We further modify equation (3) into an error correction model (ECM) as

$$
\begin{aligned}
& \operatorname{Ln} R_{t}=\delta_{t}+\sum_{n=1}^{N} \sum_{j=0}^{q} \eta_{t, j} \Delta \mathrm{X}_{t-j} \sum_{k=1}^{P} \varphi_{t, n} \Delta \mathrm{R}_{t-k}+\varpi \Delta N_{t}+ \\
& +\psi_{t} \mu_{t-1}+e_{t}
\end{aligned}
$$



domestic VAT is assessed on domestic private consumption, import VAT is assessed on imports.

\subsection{Estimation of VAT Elasticity Coefficients: The Divisia Method}

Equations (3), (4) and (5) yield buoyancy coefficients but not elasticity coefficients. The literature identifies four techniques for obtaining elasticity coefficients. These are the proportional adjustment (PA) method pioneered by Mansfield, (1972) and Prest (1962); the constant rate structure (CRS) method by Chelliah and Sheetal (1974) and Andersen (1973); the dummy variable (DV) approach by Singer (1968), Wawire (2011) and Twerefou et al. (2010); and finally, the Divisia index approach used by Choudhry (1979).

We employ the Divisia method. Its key strength is that it does not require any adjustment of the historical series to discretionary tax changes because the index itself offers the automatic growth of revenue. Moreover, a number of changes in VAT rate have been made. In addition, there have been a number of amendments to the VAT laws regarding exemptions. Finally, in 2010, the three autonomous revenue agencies in Ghana were integrated into one institution: the GRA. Using the dummy variable techniques will require including a dummy for each of these several reforms. Obviously, this would lead to a dummy variable trap. With the Divisia Index approach, therefore, no dummies are needed. Importantly, since the index considers the integrals of all discretionary changes along the tax yield curve, it provides an exact index of discretionary measures of the underlying equation. The key limitation of the Divisia Index method is that it is unable to estimate the revenue effect of specific tax measures. For details of the derivation and theoretical basis of the Divisia Index, refer to Solow (1957); Star and Hall (1976), Bilquees (2004) and Choudhry (1979) also provide the detailed derivations and their application. The key equations of the model are outlined as follows:

$\operatorname{Ln} \Gamma(n)=\log \frac{R(n)}{R(0)}-\sum_{1}^{k} \Omega^{*} \log \frac{Y_{t}(n)}{Y_{t}(0)}$

where $\Gamma(n)$ is the index of discretionary VAT measures, $R(n)$ is the tax revenue in period $\mathrm{n}, R(0)$ is the tax revenue in period $0, Y_{t}(n)$ is the tax base in pe$\operatorname{riod} \mathrm{n}, Y_{t}(0)$ is the tax base in period 0 , and $\Omega^{*}$ is the weight for the growth rate of automatic tax revenue
- a weighted sum of growth rates of the tax bases. Equation (6) shows that the growth rate of the discretionary tax revenues is the difference between the growth rate of total revenues and growth rate of automatic tax revenues, where the latter is a weighted sum of the growth rate of the (proxy) bases, $\Omega^{*}$. The elasticity coefficient is then obtained by applying the formula:

$\delta^{*}=\beta-\frac{\log \Gamma(n)}{\log \left(Y_{i(n)} / Y_{i}(0)\right.}$

where $\delta^{*}$ is VAT elasticity coefficient, while $\beta$ is the VAT buoyancy coefficient (regression estimates obtained from equations (3), (4) and (5)).

\subsection{Robustness}

We test for both serial correlation and heteroskedasticity in each model. We employ the Newey-West estimator for models with both heteroskedasticity and autocorrelation (Newey \& West, 1994;1987), while the Prais-Winsten estimator is used in cases in which only autocorrelation is detected (Wooldridge, 2003). The Linktest is performed to ascertain the correctness of the model specification. The stationary test is also performed on residuals of the regression results to check the robustness of the results. If the residuals are stationary, it indicates that the regression results are robust. The results of the Linktest and augmented Dickey-Fuller (ADF) tests are reported under the estimation.

\subsection{Unit Root Test}

Common issues in time series data analysis are nonstationarity and cointegration. If the variables are nonstationary, estimation of equations (3), (4) and (5) with OLS can provide spurious results (unless the variables are cointegrated). We first test for unit root with the augmented ADF test. All of the variables are tested with a linear trend and/or intercept because they were found to be significant at 1 percent (see Table 3).

The ADF test statistics are found to be greater than the critical values at the 5 percent significance level, indicating that all of the relevant variables are found to be stationary in $[\log ]$ levels (i.e., I(0)) at $5 \%$ (see Table 3). The only exception is real GDP, which is stationary at first difference (i.e., I (1)). 
Table 3. Unit Root Test Results

\begin{tabular}{lcc}
\hline & & ADF Test \\
\cline { 2 - 3 } Variables & Test stats & $\mathbf{1}^{\text {st }}$ diff \\
\hline GDP (Total Value Added) & -3.246 & $-9.101^{* * *}$ \\
Household Final Consumption & $-3.538^{* *}$ & \\
Total Consumption & $-7.391^{* * *}$ & \\
Imports & $-4.582^{* * *}$ & \\
Domestic VAT & $-9.673^{* * *}$ & \\
Import VAT & $--5.132^{* *}$ \\
Total VAT Revenue & $-4.357^{* * *}$ \\
\hline
\end{tabular}

Note:

ADF Test: Critical values (levels) : 1\% (-4.130), 5\% (-3.491)

Critical values (first difference): 1\% (-4.135), 5\% (-3.493)

***, **, and ${ }^{*}$ denote $1 \%, 5 \%$ and $10 \%$ significance levels, respectively.

\section{Data Sources and Description}

The study uses quarterly data covering 2000-quarter one (2000 q1) to 2014-quarter four (2014 q4). The tax data are compiled from the GRS, Bank of Ghana (BoG), annual and quarterly reports and various budget statements from the Ministry of Finance (MoF). Quarterly data on GDP from 2006 to 2014 are readily available on the Ghana Statistical Service (GSS) website. The GDP series from 2000 to 2005 and that of the value of imports are however compiled from various annual, quarterly and monthly reports by the GSS, the BoG, the Ministry of Trade and Industry and the MoF. The use of nominal values is said to bias the coefficient toward unity, thereby underestimating the magnitude of the estimates (Haughton, 1998). All of the data used are in real values. Effective 1 July 2007, the current currency of the country, the cedi ( $\$$ ), was redenominated to the Ghana cedi $(\mathrm{GH})$ ). Per this change, ten thousand cedis were equivalent to one Ghana cedi (i.e., four zeros were removed). The redenomination did not affect the intrinsic value of the currency (the value was the same). Since data recorded before the redenomination were expressed in the old unit, a plot of most data from July 2007 showed a sharp break since data before July 2007 had four more zeros (in ten thousand). For consistency, the data before July 2007 were converted to the new unit by dividing by 10,000 . This conversion removes the breaks from the data.

\section{Results and Discussions}

\subsection{Trends in Key Variables}

For the sake of brevity, only the trends in the contributions of import and domestic VAT to total VAT revenue are discussed (see Figure 3). The trends in private consumption, import value, total VAT, import VAT and domestic VAT revenues are presented in Appendix 2.

On average, the contribution of import VAT to total VAT revenue (64.46 percent) is almost twice that of domestic VAT (35.52 percent). This development underscores the dominance and importance of import VAT in the generation of Ghana's tax revenue; however, this dominance is gradually eroding. The contribution of import VAT decreased gradually from approximately 71 percent in 2001 to 60 percent in 2014 as that of domestic VAT increased steadily from 29.32 percent in 2001 to approximately 40 percent in 2014 . The dominance of the import VAT reflects two things. The first is that Ghana's economy is not only a net 


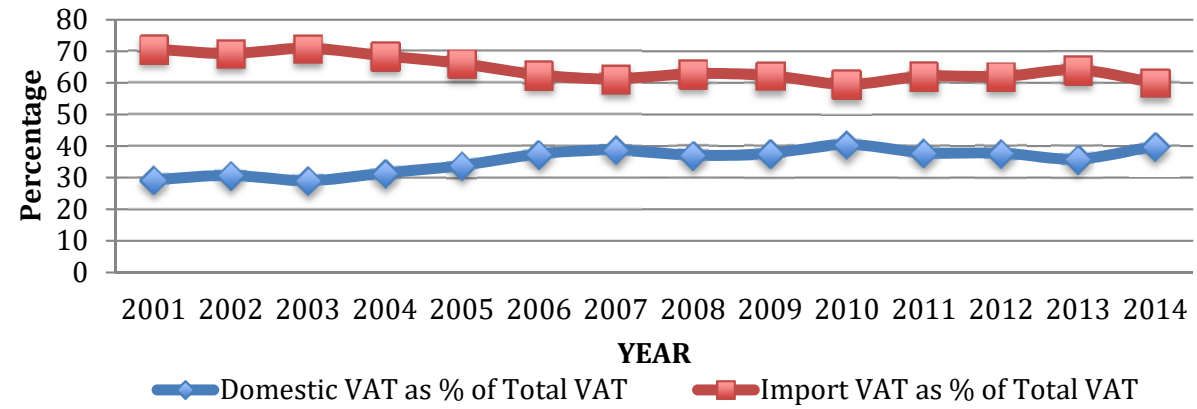

Figure 3. Contribution of Domestic and Import VAT to Total VAT Revenue

importer but is also known for its high dependence on imports for domestic consumption. The country was ranked 78th in terms of imports worldwide in 2013 and 2014. Merchandise imports are dominated by manufactured goods, which accounted for an annual average of 65 percent over the reported period, followed by fuel (17 percent) and all food items (6\%) (Vacu \& Odhiambo, 2017). Under such circumstances, the VAT on imported goods has the tendency to be higher. Second, the efficiency of import VAT revenue collection could be higher than that of domestic VAT because import VAT is collected at the port/border. Therefore, voluntary compliance is likely to be high, especially with the existence of clearing automation at the ports and harbors. Unlike the import VAT, the domestic VAT revenue is more likely to be addressed with evasion and fraud because it largely depends on the sincerity of taxpayers and revenue officials since most of the activities fall within the informal sector, in which bookkeeping is generally low.

In particular, it is observed that import VAT assumed a downward trend from 2004. This period corresponds to the period when many generous import duties and import VAT exemptions were provided. For example, in 2004 the following packages were announced. (i) Payment of VAT on imported industrial raw materials was to be suspended and eventually zero rated, in pursuance of the government's vision of a Golden Age of Business. This policy was implemented to leverage manufacturers against the upfront cash flow problems associated with the VAT component of large imports of industrial raw materials (Republic of Ghana, 2004). (ii) In line with the government's priority of modernizing agriculture and increasing international market share, particularly for nontraditional crops and rice, import VAT on irrigation pumps was also removed (Republic of Ghana, 2004). (iii) Finally, import duty and import VAT on inputs for the production of fishing nets and fishing ropes were removed (Republic of Ghana, 2004), to render the fishing industry competitive through a reduction in operation costs. The offering of such packages was not without abuses. It was stated categorically in the 2006 budget that, for a 7-month period (January to July 2005), import duties and import VAT that were given away in exemptions amounted to a total of $\$ 895.07$ billion (Republic of Ghana, 2006).

With regard to domestic VAT, the trends show that its contribution to total VAT revenues not only decreased from almost 31 percent in 2002 to 29 per- 

Table 4. Discretionary, Automatic and Total Growth of VAT Revenues (Growth in Percentages)

\begin{tabular}{lcccc}
\hline & Total VAT & Domestic VAT $^{+}$ & Domestic VAT $^{++}$ & Import VAT $^{+}$ \\
\hline Discretionary growth & -1.63 & 1.28 & 1.17 & -1.81 \\
Automatic growth & 3.65 & 0.78 & 0.89 & 3.26 \\
Total growth & 2.02 & 2.06 & 2.06 & 1.45 \\
\hline
\end{tabular}

Note:

$+=$ Base household final consumption

$++=$ Base total consumption $=$ Household final consumption + Government on goods and services

that in 2013 was attributed mainly to the increase in VAT rate from 12.5 percent to 15.0 percent (Bank of Ghana, 2014).

In contrast, growth in import VAT is found to be driven exclusively by growth in its base, i.e., imports. Whereas discretionary tax measures cumulatively reduce revenue growth by 1.81 percent, the increase in imports raises import VAT by 3.26 percent. The observed negative effect of discretionary tax measures on import VAT revenues can largely be attributed to shrinking of the tax base due to large import exemptions which have been granted under the VAT regime. For example, goods and services imported on behalf of and for the president of Ghana, the blind, deaf and dumb, and churches and religious bodies are exempted from import VAT. In addition, items imported by non-governmental organizations (NGOs), as well as materials imported for use in the production of nets, twines and goods produced for fishing, infants' foods, machinery, apparatus and spare parts for agricultural purposes, and chemicals for agricultural purposes, are exempted. Moreover, exemptions are granted to specific goods for specific uses, such as Volta Aluminum Company Ltd. (VALCO) and Volta River Authority (VRA). These provisions have been abused seriously due to the inconsistencies in Ghana's tariff regime.

Moreover, Ghana's statutes contain widespread tariffs and other import duty exemptions schemes, which effectively allow many operators not to pay customs duties, VAT and other taxes. As a result, approximately 25 percent of the otherwise payable import duties are forgone annually in exemptions of various sorts (World Trade Organisation [WTO], 2014). It is estimated that, in 2012 alone, direct tax and VAT exemptions amounted to US\$876 million, representing approximately 67 percent of all exemptions (Republic of Ghana, 2012). The revenue loss from exemptions granted in duties and taxes is said to have undermined the tax revenue performance (Republic of Ghana, 2014).

\subsection{Long-term VAT Buoyancy and Elasticity Estimations}

The previous subsection reports the cumulative effects of all discretionary tax measures (DTMs) on VAT revenue. This subsection provides the buoyancy and elasticity coefficients obtained from the long-term regression results from equation (3). The buoyancy coefficients are obtained by the DOLS estimations, while the elasticity coefficients are obtained using the Divisia index to adjust the estimated buoyancy coefficients. The results are reported in Table 5.

Column 1 reports long-run (LR) total VAT revenue buoyancy and elasticity. Columns 2, 3 and 4 report the case for the disaggregated VAT revenues. Specifically, columns 2 and 3 report the results for domestic VAT when private consumption and total consumption are used as tax bases, respectively, while column 4 reports the results for import VAT. The models pass all of the diagnostic tests. The Linktests show that, in each of the models, the coefficient of hat is significant, but that of hat square has no explanatory power. This outcome suggests that an inclusion of additional variables will not necessarily further improve the model, implying that the model is well specified. Moreover, the ADF test shows that coefficient of the regression residual is stationary at 1 percent, indicating that the results are robust. 
Table 5. Long-run Buoyancy and Elasticity

\begin{tabular}{|c|c|c|c|c|}
\hline & (1) & (2) & (3) & (4) \\
\hline & TVAT & DVAT $^{+}$ & DVAT $^{++}$ & IVAT \\
\hline LR Buoyancy & $1.018^{* * *}$ & $1.454^{* * *}$ & $1.482^{* * *}$ & $0.966^{* * *}$ \\
\hline LR Elasticity & $1.88^{* * *}$ & $0.824^{* * *}$ & $0.852^{* * *}$ & $2.94^{* * *}$ \\
\hline Divisia Index & -0.87 & 0.63 & 0.57 & -1.98 \\
\hline \multirow[t]{2}{*}{ GDP Per Capita } & $0.922^{* * *}$ & $1.5199 * * *$ & $3.4785^{* *}$ & $0.288^{* * *}$ \\
\hline & $(0.0721)$ & $(0.2304)$ & $(0.5602)$ & $(0.0904)$ \\
\hline \multirow[t]{2}{*}{ Agric Share of GDP } & $-0.0598^{* * *}$ & $-1.8381^{* *}$ & -0.5260 & \\
\hline & (0.00168) & $(0.5602)$ & $(0.1673)^{* *}$ & \\
\hline Linktest hat (p-value) & $0.96(0.13)^{* * *}$ & $1.92(0.75)^{* * *}$ & $1.98(0.69)^{* * *}$ & $1.22(0.15)^{* * *}$ \\
\hline Linktest hat-sq ( $p$-val) & $-0.010(0.01)$ & $-0.08(0.075)$ & $-0.08(0.069)$ & $-0.02(0.015)$ \\
\hline ADF Residual (p-val) & $3.100^{* * *}$ & $2.374^{* *}$ & $2.373^{* *}$ & $3.798^{* * *}$ \\
\hline Observations & 57 & 57 & 57 & 57 \\
\hline R-squared & 0.99 & 0.851 & 0.854 & 0.99 \\
\hline
\end{tabular}

Note:

Standard errors in parentheses ${ }^{* * *} p<0.01,{ }^{* *} p<0.05,{ }^{*} p<0.1$

ADF critical values: $1 \%(-2.616) ; 5 \%(-1.950)$

$+=$ tax base is household final consumption

$++=$ tax base is total consumption (Household final consumption + Government consumption of goods and services)

From column 1, the coefficient of total VAT revenue (1.018) is statistically significant at one percent and not significantly different from unity. This finding indicates that one-percent growth in both VAT base and discretionary changes cumulatively increases total VAT revenues by 1.018 percent in the long term. This coefficient is relatively smaller than that of Twerefou et al. (2010), who obtained long-term VAT/sales tax buoyancy of 1.41 for Ghana. As explained earlier, Twerefou et al. (2010) merged sales tax and VAT data, with the latter constituting only 7 of the 37 annual data series. Consequently, the results could possibly reflect more sales tax than VAT. However, the findings are in line with Dudine and Jalles (2017), who obtained a LR buoyancy coefficient of 1.075 for a goods and service tax for low income countries.

Desirably, tax buoyancy is expected to be greater than unity to imply that the tax revenue is able to im- prove the fiscal stance of the economy through the revenue side of the budget. However, in contrast, Ghana's total VAT does not seem to exhibit strong long-term buoyancy. A number of factors might explain this low coefficient. First, the results point to composition effects. Total VAT is made up of both domestic VAT and import VAT. As already seen in Figure 3, the latter's contribution to total VAT revenue (64.46 percent) is, on average, almost twice that of domestic VAT (35.52 percent). Over the years, there has been an increase in the amount of imports not subject to VAT because of exemptions and zero rating. This expansion of imports not subject to VAT could be responsible for the low buoyancy coefficient. Furthermore, it has been argued that tax evasion and tax fraud are common features of tax administration in developing countries (Keen \& Smith, 2007). Further, the situation could be worse for Ghana's VAT administration, especially in the face of 
a large informal sector and the frequent hikes in VAT rates. Ghana's VAT rate has increased three times since its adoption in 1998. Given that these upward adjustments have always faced public agitation, there is every reason to believe that they have provided an incentive for VAT evasion and fraud.

Total VAT revenue is also found to be elastic (1.88), meaning that a one-percent increase in the VAT base automatically increases VAT revenue by 1.88 percent. This outcome is desirable because it is an indication that revenue generation is able to automatically keep pace with the growth in the tax base, which could prevent frequent changes in tax rates that can be politically and economically costly (Osoro, 1993). Furthermore, the elasticity coefficient of total VAT is found to be greater than the buoyancy coefficient, which is the case when the overall effect of discretionary tax changes is negative, indicating that growth in VAT revenue is strongly driven by growth in the tax base and that, on the whole, discretionary measures have not been very effective in driving revenue growth. The difference between the buoyancy and elasticity coefficients is -0.87 , which implies that doubling the discretionary tax measures reduces total VAT revenue by approximately 0.87 percent, which supports the results obtained under the Divisia Index that discretionary tax measures cumulatively reduce total VAT revenue by 1.85 percent over the sample period.

Disaggregating total VAT into domestic and import VAT (columns 2 and 3) shows that domestic VAT revenue is found to be buoyant with a coefficient of 1.45 (or 1.48 when total consumption is used as a base) but import VAT revenue is not buoyant. Its buoyancy coefficient is less than unity (i.e., 0.966). The results thus suggest that domestic VAT has higher long-term growth potential than import VAT, although the latter's contribution to total VAT revenue (64.46 percent) is on average almost twice that of domestic VAT (35.52 percent) (as shown in Figure 3). In terms of elasticity, domestic VAT revenue is found to be positive but less than unity (i.e., 0.82). The magnitude of the coefficient suggests that, when the revenue effects of discretionary measures are removed, a one-percent increase in private consumption (or total consumption) increases domestic VAT revenue by approximately 0.8 percent. The positive sign, conversely, suggests that domestic VAT revenue growth is driven by both growth in its tax base (automatic growth) and changes in discretionary tax measures. However, the automatic growth is stronger (0.82) relative to discretionary policies (0.63). From column (4), the elasticity coefficient of import VAT revenue is not only greater than unity (i.e., 2.94) but also considerably greater than the buoyancy coefficient (0.94). Thus, when the effects of discretionary tax measures are removed, a one-percent increase in import value is able to increase import VAT revenues by 2.9 percent.

Although the elasticity coefficient of import VAT appears to be relatively higher than that of the total VAT, it is desirable because it indicates that import VAT is automatically able to keep pace with import growth. The higher elasticity coefficient could be attributed to the use of full automation procedures of clearance at Ghana's major ports and harbors. In 2003, in a bid to improve revenue collection efficiency at the ports and harbors, the Ghana Revenue Authority installed full automation systems comprised of two components, namely, the Ghana Community Network (GCNet) and the Ghana Customs Management Systems (GCMS). The GCMS provides a fully integrated computerized system for the management of customs declarations and related activities The GCNET, conversely, is the platform that enables the GCMS to share data with all of the parties engaged in the processing of customs clearances (Andoh, 2017). Studies have shown that automating the tax administration not only reduces the compliance and administration costs but also leads to increased effectiveness in revenue collection (Vasudevan, 2007).

\subsection{Results from Short-run Estimations}

Similar to the long term, we employ the Divisia Index to isolate the short-term elasticity from buoyancy coefficients obtained from estimating equation (2). The results are presented in Table 6.

Columns 1, 2, 3 and 4 report the short-run buoyancy and elasticity coefficients for total VAT, domestic VAT (when household final consumption is used as the base), domestic VAT (when total total consumption is used as the base) and import VAT, respectively. In line with expectations, specifically in column (1), the shortrun buoyancy and elasticity coefficients for total VAT are positive at one percent, suggesting that VAT revenue moves in the same direction as its respective base. 
Table 6. Short-run Buoyancy and Elasticity of VAT Revenues

(1)

\begin{tabular}{|c|c|c|c|c|}
\hline & Total VAT & Domestic VAT $^{+}$ & Domestic VAT ${ }^{++}$ & Import VAT \\
\hline \multirow[t]{2}{*}{ Buoyancy } & $0.4357^{* *}$ & $1.732^{* *}$ & $1.796^{* *}$ & $0.2106^{* *}$ \\
\hline & $(0.1351)$ & $(0.722)$ & $(0.723)$ & $(0.1021)$ \\
\hline Elasticity & $1.31^{* *}$ & $1.10^{* *}$ & $1.23^{* *}$ & $2.19^{* *}$ \\
\hline \multirow[t]{2}{*}{ ECTerm } & $-0.1037^{* *}$ & $-0.902^{* * *}$ & $-0.966^{* * *}$ & $-0.2877^{* *}$ \\
\hline & $(0.3761)$ & $(0.186)$ & $(0.186)$ & $(0.1258)$ \\
\hline
\end{tabular}

\section{Diagnostics}

\begin{tabular}{|c|c|c|c|c|}
\hline Jacque-Bera & 0.7906 & 0.40519 & 0.3645 & 0.6646 \\
\hline LM Test & 0.2336 & 0.1151 & 0.1158 & 0.2579 \\
\hline Observations & 58 & 58 & 58 & 57 \\
\hline
\end{tabular}

Note:

Standard errors in parentheses ${ }^{* * *} p<0.01,{ }^{* *} p<0.05,{ }^{*} p<0.1$

$+=$ tax base is household final consumption

$++=$ tax base is total consumption (Household final consumption + Government consumption of goods and services)

The buoyancy coefficient for total VAT is 0.435 , while the elasticity coefficient is greater than unity (1.31). An elasticity coefficient greater than 1 implies that total VAT revenue exhibits greater fluctuations over changes in its base. Twerefou et al. (2010) obtained a short-term buoyancy coefficient of 0.42 and elasticity of 0.7. The difference could be attributed to data since their work was based primarily on sales tax. Similarly, domestic VAT revenue exhibits positive but greater fluctuations when total consumption is used as a base (both the buoyancy and elasticity coefficients are positive and greater than unity). However, narrowing the base to only household final consumption reduces the elasticity coefficient to almost unity, suggesting that domestic VAT becomes less volatile when household consumption is used as a base, reflecting the general stability of household consumption relative to government consumption. Individuals are more likely than governments to smooth consumption in response to fluctuations over the business cycle. As shown in column (4), the import VAT elasticity coefficient of 2.19 indicates that import VAT is highly variable over fluctuations in imports, given discretionary policies.

All of the coefficients for the speed of adjustment are statistically significant and have the expected negative signs. The speed of adjustment indicates that 29 percent of the deviations in import VAT revenue from its long-run value are corrected for in the next period. Those of domestic VAT are 90 percent with respect to household final consumption and 96 percent when total consumption is used as the base.

The difference between the long-term import VAT buoyancy coefficient (0.97) and that of the short-term coefficient (0.22) suggests that there is a significantly large divergence in the responses of import VAT between the two time periods. However, the speed of adjustment shows that approximately 29 percent of the deviations are corrected for in the next period. The negligible divergence between the long- and short-term buoyancy coefficients, coupled with the high adjustment parameter of the domestic VAT revenue, suggest that reactions of domestic revenues to changes in their 
Table 7. Short-run Asymmetric Responses of Value Added Tax

(1)

\begin{tabular}{lccc} 
& TVAT & Domestic VAT & Import VAT \\
\hline Period of Expansion & $0.471^{* *}$ & $1.371^{* *}$ & $0.403^{* * *}$ \\
& $(0.149)$ & $(0.697)$ & $0.127)$ \\
Period of Contraction & $0.473^{* *}$ & $1.26^{*}$ & $0.394^{* * *}$ \\
& $(0.148)$ & $(0.691)$ & $(0.125)$ \\
EC Term (Speed of Adjustment) & $-0.218^{* *}$ & $-0.274^{* * *}$ & $-0.439^{* * *}$ \\
& $(0.057)$ & $(0.046)$ & $(0.117)$ \\
\hline Jacque-Bera Test & 0.255 & 0.3646 & 0.579 \\
LM Test & 0.464 & 0.5656 & 0.586 \\
Observations & 58 & 58 & 57 \\
R-squared & 0.662 & 0.557 & 0.566 \\
\hline
\end{tabular}

Note:

Standard errors are in parentheses ${ }^{* *} p<0.01,{ }^{* *} p<0.05,{ }^{*} p<0.1$

+ denotes that tax base is private consumption

base exhibit no fundamental differences between the short and long term, indicating that there is no significant overshooting or undershooting, which is an indication of a rather nondynamic pattern in domestic VAT in Ghana. Evidence of growth and stability is found for almost all of the measures of VAT. Both the longand short-term elasticity coefficients for total VAT are greater than unity, suggesting that total VAT experiences growth but, at the same time, is highly variable. A similar observation is made for import VAT.

\subsection{Asymmetric Responses}

The results for the asymmetric responses are obtained by estimating equation (3). They are reported in Table 7.

Columns 1 and 3 report the results for total VAT and import VAT, respectively. The total VAT coefficients for the periods of expansion and contraction in the tax base are 0.471 and 0.473 , respectively, while those for import VAT are 0.40 and 0.39 respectively. This finding suggests that total VAT revenue and import VAT revenue do not exhibit any significant variability in either period. Moreover, in statistical terms, the coefficients are significantly less than one, suggest- ing that total VAT revenue and import VAT revenue cannot serve as good automatic stabilizers in both contractionary and expansionary periods. The case is, however, different for domestic VAT revenue. The coefficients are statistically significant and are greater than 1 , suggesting greater variability and hence better revenue stability during both good and bad times.

\subsection{Decomposition of Elasticities}

We now decompose the elasticity into tax-to-GDP, base-to-GDP and tax-to-base, enriching our understanding of the critical source of the revenue growth. The decomposition is presented in Table 8 .

Positive tax-to-GDP and tax-to-base coefficients are observed for total VAT in both the short and long term. Specifically, in the long term, one percent growth in GDP leads to 1.11 percent growth in total VAT revenues, while one percent growth in the base leads to 1.88 percent growth in total VAT revenues. The base-to-GDP is, however, inelastic, indicating weaker responsiveness of the tax base to growth in GDP (variation exists among components). The estimates for total VAT differ from those of Twerefou et 
Table 8. Decomposition of Tax Elasticities

\begin{tabular}{|c|c|c|c|c|}
\hline & Taxes & Tax-to-GDP & Base-to-GDP & Tax-to-Base \\
\hline \multicolumn{5}{|l|}{ Long-run } \\
\hline & Domestic VAT ${ }^{+}$ & - & 0.82 & 0.82 \\
\hline & Domestic VAT ${ }^{++}$ & 0.82 & 0.89 & 0.85 \\
\hline & Import VAT & 2.23 & 0.86 & 2.94 \\
\hline & Total VAT ${ }^{+++}$ & 1.11 & 0.95 & 1.88 \\
\hline \multicolumn{5}{|l|}{ Short-run } \\
\hline & Domestic VAT ${ }^{+}$ & - & 1.17 & 1.10 \\
\hline & Domestic VAT ++ & 0.91 & 1.25 & 1.23 \\
\hline & Import VAT & 2.22 & 0.42 & 2.19 \\
\hline & Total VAT+++ & 1.35 & 0.87 & 1.31 \\
\hline
\end{tabular}

Note:

$+=$ tax base is household final consumption

$++=$ tax base is total consumption (Household final consumption plus Government consumption of goods and services)

$+++=$ tax base is total consumption plus total imports

- denotes coefficient is as obtained from domestic VAT ${ }^{++}$

al. (2010), who obtained a base-to-GDP elasticity coefficient of 0.79 before tax reforms and 1.11 after tax reforms in 1983. The study further obtained tax-tobase coefficients of 0.72 and 1.31 before and after the tax reform, respectively. As already pointed out, these figures reflect more sales than VAT. All three decomposed coefficients for domestic VAT estimates are less than unity in the long term. The inelastic base-to-GDP elasticity suggests that the growth in GDP is unable to induce strong growth in the base. The coefficient of tax-to-base is also inelastic and, at the same time, smaller than that of base-to-GDP elasticity, suggesting a weaker revenue-to-base response than base-to-GDP response. This observation largely reflects the problem of tax evasion and avoidance. With the presence of large informality in Ghana, it is quite easy to evade and avoid domestic VAT. The tax-to-base elasticity coefficients for import VAT are positive and greater than unity in both the long and short term. However, the base-to-GDP coefficients for both time periods are less than unity although positive. This finding suggests that the key setback to import VAT revenue growth lies in the low responsiveness of the base to growth in GDP.

\section{Conclusions and Recommendations}

In terms of a summary, the study finds that, although import VAT dominates total VAT in Ghana, its dominance falls over time as domestic VAT's contribution gains momentum. Moreover, both the Divisia computation and the regression analysis showed that all three VAT measures used in the study have experienced growth. Furthermore, all of the discretionary tax measures undertaken over the period have cumulatively reduced the growth of total VAT and import VAT but rather have enhanced the growth of domestic VAT revenues. Thus, while growth in domestic VAT revenue is driven by both discretionary tax measures and growth in the tax base, growth in total VAT and import VAT revenues are driven solely by growth in the respective bases. The elasticity coefficients from the error correction model show that revenues from all of the VAT measures vary positively with their respective bases but, at the same time, exhibit high variability in the short term. On the whole, a critical observation emerging from this study is that, while the key problem of domestic VAT lies in the inability of growth in the base to induce stronger automatic growth in tax 
revenues, that of import VAT revenues is the inability of the base to grow automatically in response to GDP growth. This finding suggests that there cannot be a one-size-fits-all approach to boosting VAT revenues in Ghana. The approach to improving VAT revenue should be multifaceted and specific; otherwise, the revenue potential of VAT will remain fragile.

The empirical findings have of important implications for Ghana's VAT regime and therefore the fiscal system. First, the findings suggest that, in the long term, total VAT revenue has been more elastic than the erstwhile sales tax. However, in terms of buoyancy, its coefficient has been relatively smaller. For example, compared with the two previous studies of sales tax, our study obtains long-term total VAT elasticity and buoyancy coefficients of 1.88 and 1.018 , respectively. Kusi (1998) obtained 1.7 and 1.58, respectively, while Twerefou et al. (2007), obtained 1.09 and 1.41. Thus, in comparative terms, total VAT generally appears to possess a better ability (relative to the sales tax) to automatically maintain pace with the growth in the tax base. However, lower buoyancy implies that VAT (relative to sales tax) was greatly damaged by the type of discretionary policies implemented during the sample period.

Second, the positive and higher (greater than unity) elasticity coefficients suggest that, desirably, the VAT revenues grow automatically with growth in the base, ceteris paribus. This outcome underscores that growth in the appropriate tax base is critical for growth in VAT revenue. In this regard, this study recommends that greater emphasis must be placed on improving the respective tax bases. As shown by the findings, the informal economy (proxied by agriculture share of GDP) has a negative effect on VAT revenue. Therefore, formalizing the informal sector is believed to have a great impact in broadening the tax base. The current government has initiated a number of measures toward digitizing the entire economy. The specific measures include the provision of national biometric identification cards (Ghana card) for all citizens by the end of 2018 and a mandatory taxpayer identification number (TIN) for all residents by end of April 2018. We recommend that these policies be pursued relentlessly since they could go a long way toward reducing the size of the informal sector and the associated level of tax evasion.
Finally, the empirical results show that discretionary tax measures that were in place during the study period have cumulatively negative effects on import VAT revenue.

In light of the above findings, we recommend that tax authorities should take a critical look at import exemptions regimes. A major concern is that tax exemption provisions in Ghana are not always clear and hence can easily be abused. Although there might be justifiable reasons for providing import VAT exemptions, such exemptions should be provided sparingly and should also be monitored to eliminate abuses. Such exemptions have contributed to the erosion of the import VAT base, creating the situation where, although import VAT revenue responds strongly to inbuilt growth of the base, the response of the base to growth in the economy is very weak.

\section{References}

Adam, C. S., Bevan, D. L., \& Chambas, G. (2001). Exchange rate regimes and revenue performance in Sub-Saharan Africa. Journal of Development Economics, 64(1), 173-213.

AfDB. (2014). African Economic Outlook: Promoting Youth Employment. Retrieved from https://www. undp.org/content/dam/rba/docs/Reports/African\%20Economic\%20Outlook\%202012\%20En.pdf

AfDB. (2012). African Economic Outlook. Retrieved from https://www.undp.org/content/dam/rba/docs/ Reports/African\%20Economic\%20Outlook\%20 2012\%20En.pdf

Alagidede, P., Baah-Boateng, W., \& Nketiah-Amposah, E. (2013). The Ghanaian economy: An overview. Ghanaian Journal of Economics, 1, 4-34.

Amo-Yartey, C. (2014). Improving Fiscal Management in Ghana: The Role of Fiscal Policy Rules. Legislative Alert, 21(1), 1-8. Retrieved from http://ieagh. org/wp-content/uploads/2014/08/IEA-Legislative-Improving-Fiscal.pdf

Andersen, S. P. (1973). Built-in Flexibility of Sensitivity of the Personal Income Tax in Denmark. Swedish Journal of Economics, 75, 23-38.

Andoh, F. K. (2017). Taxable Capacity and Efforts of Ghana's Value-Added Tax. African Review of Economics and Finance, 9(2), 255-284.

Annacondia, F., \& van der Corput, W. (2012). Overview of General Turnover Taxes and Tax Rates 

Haughton, J. (1998). Estimating Tax Buoyancy, Elasticity, and Stability (African Economic Policy Paper No. 11). Retrieved from http://pdf.usaid.gov/pdf_ docs/PNACE024.pdf

International Monetary Fund. (2015). Ghana Second Review under the Extended Credit Facility Arrangement and Request for Waiver for Nonobservance of Performance Criterion -Debt Sustainability Analysis. Wahington, DC. Retrieved from https://www. imf.org/en/Publications/CR/Issues/2016/12/31/ Ghana-Second-Review-Under-the-ExtendedCredit-Facility-Arrangement-and-Request-forWaiver-43628

Kargbo, B. I. B., \& Egwaikhide, F. O. (2012). Tax Elasticity in Sierra Leone: A Time Series Approach. International Journal of Economics and Financial Issues, 2(4), 432-447.

Keen, M., \& Lockwood, B. (2010). The value added tax: Its causes and consequences. Journal of Development Economics, 92, 138-151.

Keen, M., \& Smith, S. (2007). VAT Fraud and Evasion: What do we know and what can be done (Working Paper, No. 07/31). International Monetary Fund.

Kendrick, S. M. (1939). The Ability-to-Pay Theory of Taxation. The American Economic Review, 29(1), 92-101.

Khattry, B., \& Rao, M. J. (2002). Fiscal Faux Pas?: An Analysis of the Revenue Implications of Trade Liberalization. World Development, 30(8), 14311444.

Koester, G. B., \& Priesmeier, C. (2012). Estimating $d y$ namic tax revenue elasticities for Germany (Working Paper No 23/2012). Frankfurt: Deutsche Bundesbank. Retrieved from https://www.econstor.eu/bitstream/10419/64816/1/726798541.pdf

Kusi, N. K. (1998). Tax Reform and Revenue Productivity in Ghana (Research Paper No. 74). Nairobi: African Economic Research Consortium. Available at https://opendocs.ids.ac.uk/opendocs/handle/123456789/2210

Mansfield, C. Y. (1972). Elasticity and Buoyancy of Tax System: A Method Applied to Paraguay. Staff Papers, 19(2), 425-446.

Masih, A., \& Masih, R. (2001). Long and short term dynamic causal transmission amongst international stock markets. Journal of International Money and Finance, 20, 563-587.
Mensah, B. (2017, March 31). Value Added Tax Amendment Bill Passed. Retrieved from http:// www.ghananewsagency.org/politics/value-addedtax-amendment-bill-passed-115081

Milwood, T.-A. T. (2011). Elasticity and Buoyancy of the Jamaican Tax System. Kingston: Bank of Jamaica. Retrieved from http://boj.org.jm/uploads/ pdf/papers_pamphlets/papers_pamphlets_Elasticity_and_Buoyancy_of_the_Jamaican_Tax_System.pdf

Newey, W., \& West, K. (1987). A Simple, Positive SemiDefinite Heteroskedasticity and Autocorrelation Consistent Covariance Matrix. Econometrica, 55, 703-708.

Newey, W., \& West, K. (1994). Automatic Lag Selection in Covariance Matrix Estimation. Review of Economic Studies, 61, 631-635.

OECD. (2016). Revenue Statistics in Africa. Retrieved from http://dx.doi.org/10.1787/9789264253308-en-fr

Osei, R. D., \& Quartey, P. (2005). Tax Reforms in Ghana (Working Paper No. 2005/66). The World Institute for Development Economics Research. Retrieved from https://www.wider.unu.edu/sites/ default/files/rp2005-66.pdf

Osoro, N. (1993). Revenue Productivity Implications of Tax Reform in Tanzania (Research Paper No. 20). African Economic Research Consortium. Retrieved from http://opendocs.ids.ac.uk/opendocs/bitstream/ handle/123456789/2037/No 20.pdf?sequence $=1$

Phillips, P. C. B., \& Hansen, B. E. (1990). Statistical inference in instrumental variables regression with I(1) processes. Review of Economics Studies, 57(99-125).

Piggott, J., \& Whalley, J. (2001). VAT Base Broadening, Self Supply, and the Informal Sector. American Economic Review, 91, 1084-94.

Prest, A. R. (1962). The sensitivity of yield of personal income tax in the United Kingdom. Economic Journal, 52, 576-596.

PricewaterhouseCoopers. (2013, July). Amendment of Value Added Tax Act, 1998 (Act 546) as part of interim fiscal measures. Retrieved from https://www. pwc.com/gh/en/assets/pdf/ghana-on-point-vatamendment-july-2013.pdf

Prichard, W. (2009). The Politics of Taxation and Implications for Accountability in Ghana 1981-2008 (Research Paper No. 330). Institute for Develop- 
ment Studies. Retrieved from https://www.ids. ac.uk/files/dmfile/wp330.pdf

Republic of Ghana. (2002). Budget Statement and Economic Policy for the 2002 Financial Year. Presented by the Minister of Finance and Economic Planning: Accra, Ghana. Retrieved from https://www. mofep.gov.gh/budget-statements/2002

Republic of Ghana. (2003). Budget Statements and Finanacial Policy for 2003. Accra, Ghana: Ministry of Finance. Retrieved from https://www.mofep. gov.gh/budget-statements/2003

Republic of Ghana. (2004). 2004 National Budget Statement. Accra, Ghana. Retrieved from https:// www.mofep.gov.gh/budget-statements/2004

Republic of Ghana. (2006). Budget Statement and Economic Policy for the 2006 Financial Year. Presented by the Minister of Finance and Economic Planning : Accra, Ghana. Available at https://www. mofep.gov.gh/budget-statements/2006

Republic of Ghana. (2012). Budget Statement and Economic Policy for the 2006. Retrieved from https:// www.mofep.gov.gh/sites/default/files/budgetstatements/2012_budget.pdf

Republic of Ghana. (2014). Budget Statement and Economic Policy for the 2014 financial Year. Presented by the Minister of Finance and Economic Planning : Accra, Ghana. Retrieved from https://www.mofep. gov.gh/budget-statements/2014

Republic of Ghana. (2017). Budget Statement and Economic Policy for the 2017 Financial year. Presented by the Minister of Finance and Economic Planning : Accra, Ghana. Retrieved from https://www.mofep. gov.gh/news/2017-03-02/2017-budget-statementand-economic-Policy

Saikkonen, P. (1991). Asymptotically Efficient Estimation of Cointegration Regressions. Econometric Theory, 7, 1-21.

Singer, N. M. (1968). The Use of Dummy Variable in Establishing the Income Elasticity of State Income Tax Revenue. National Tax Journal, 21, 200-204.

Sobel, R. S., \& Holcombe, R. G. (1996). Measuring the Growth and Variability of Tax Bases over the Business Cycle. National Tax Journal, 49(4), 535-52.

Solow, R. M. (1957). Technical Change and the Aggregate Production Function. The Review of Economics and Statistics, 39(3), 312-320. Retrieved from http://www.jstor.org/stable/pdf/1926047.pdf
Star, S., \& Hall, R. (1976). An Approximate Divisia Index of Total Factor Productivity. Econometrica, 44(2), $257-263$.

Stock, J., \& Watson, M. (1993). A Simple Estimator of Cointegrating Vectors in Higher Order Integrated Systems. Econometrica, 61(4), 783-820.

Terkper, S. E. (1994a). Ghana: Trends in Tax Reform (1985-93). Tax Notes International, 8, 1267-1275. Terkper, S. E. (1994b). VAT in Ghana: Why it Failed. Retrieved from https://sites.hks.harvard. edu/cid/hiid/556.pdf

Twerefou, D. K., Fumey, A., Assibey, E. O., \& Asmah, E. E. (2010). Buoyancy and Elasticity of Tax: evidence from Ghana. Journal of Monetary and Economic Integration, 10(2), 36-70.

The Parliament of the Republic of Ghana. (1998a). VAT Act 546. Retrieved from http://www.nyansaafrica.com/wp-content/uploads/2015/05/11. The-VAT-Act-1998-Act-546.pdf

The Parliament of the Republic of Ghana. (1998b). VAT Regulations 1998 (L.I. 1646). Retrieved from https:/gra.gov.gh/wp-content/uploads/2018/11/ vat_regulations.pdf

The Parliament of the Republic of Ghana. (2013). VAT Act 2013 (Act 870). Retrieved from https://gra.gov. gh/wp-content/uploads/2018/11/vat_act_870.pdf

The Parliament of the Republic of Ghana. (2017). VAT Act 948. (Publication No. GPCL/A261/1,500/04/2017). Retrieved from http://gsiaonline.org/wp-content/ uploads/2018/07/Value-Added-Tax-AmemdmentACT-2017-Act-948-1.pdf

Vacu, N. P., \& Odhiambo, N. M. (2017). A Review of Imports Structure and Reforms in Ghana. Euro Economica, 36(1), 144-158.

Vasudevan, R. (2007). Changed Governance or Computerized Governance: Computerized Tax Administration Processes in Tamil Nadu, India. Journal of Tax Planning and Administration, 4(1), 101-112.

Wawire, N. (2000). Revenue Productivity Implications of Kenya's Tax System. In K. Kwaa-Prah \& A. G. M. Ahmed (Eds.), Africa in Transformation: Political and Economic (pp. 99-106). Addis Ababa: OSSREA.

Wawire, N. (2003). Trends in Kenya's Tax Ratios and Tax Effort Indices, and Their Implication for Future Tax Reforms. Egerton Journal, 4, 256-279. 
Wawire, N. (2011, March). Determinants of Value Added Tax in Kenya. Paper presented at Centre for the Study of African Economies Conference, Oxford, UK.

WoldeMariam, A. (2010). VAT revenue productivity for selected fund member countries. Washington, DC: International Monetary Fund.

Wolswijk, G. (2009). The Short- and Long-Run Tax Revenue Response to Changes in Tax Bases. Economics Bulletin, 29(3), 1960-1970.

Wooldridge, J. M. (2003). Introductory Econometrics: A modern approach (2 ${ }^{\text {nd }}$ ed.). Cincinnati, $\mathrm{OH}$ : Southwestern Publishing Group.

World Bank. (1991). Lessons on Tax Reform. Wahington DC: World Bank Publications.

World Bank. (2014). World Development Indicators. New York, NY: World Bank.

WTO. (2014). Trade Policy Review. Geneva. Retrieved from https://www.wto.org/english/tratop_e/tpr_e/ s298_e.pdf

\section{Endnotes}

1 In the textbook, the elasticity formula is the ratio of the percentage change in the tax revenue to the percentage change in the tax base. However, in econometric research, the formula is specified in a multiplicative form $R_{t}=e^{\alpha} Y_{t}^{\beta} e^{\mu_{t}}$, which is then $\log$ linearized to obtain equation (1).

\section{Acknowledgments}

We wish to express our deep appreciation to the African Economic Research Consortium (AERC) for the financial support to carry out this research as part of the first author's collaborative PhD programme (CPP). We are also grateful to the resource persons and members of the AERC's thematic Group B for various comments and suggestions that helped the evolution of this study from its inception to completion. We are indebted to Prof. Nelson Wawire and also the anonymous referees who reviewed the paper and provided comments and suggestions that helped in shaping and improving the overall quality of the paper. The findings made and opinions expressed in this paper are exclusively those of the authors. The authors are also solely responsible for content and any errors. 


\section{Appendix 1: List of VAT-Exempted Items in Ghana}

\section{Item}

Agricultural food items in the raw state and selected live animals produced in

$1 \quad$ Ghana and those imported for breeding purposes as well as animal products including edible meat and aquatic food products in their raw state

Selected agricultural inputs: Agricultural inputs including chemicals (fertilizers included), fishing equipment, and seeds and seedlings

Educational inputs and services: Textbooks and supplementary readers, newspapers, periodicals, magazines, trade catalogues, services supplied to students as part of the education program

Medical services and supply: Equipment and accessories for the supply of medical services; the supply of a medical, dental, nursing, midwifery or paramedical service; locally produced pharmaceuticals; mosquito nets.

Transportation: Domestic transportation of passengers by road, rail, and water but not including the supply of haulage or the rental or hiring of passenger and other vehicles; domestic transportation by air (exempted in 2017)

Financial Services: Financial services, excluding financial services rendered for a fee, commission, or a similar charge; and life insurance and reinsurance, whether or not rendered for a fee, commission or a similar charge

Crude oil and petroleum products: crude oil and hydrocarbon products: (a) petrol; (b) diesel; (c) liquefied petroleum gas; (d) natural petroleum gas; and (e) kerosene

Machinery, appliances and parts: Machinery and parts of machinery specifically designed for use in the following activities: (a) agriculture, veterinary practice, fishing and horticulture; (b) mining as specified in the mining list; (c) manufacturing; (d) railway and tramway; (e) upstream petroleum operations as specified in the petroleum list; and (f) dredging

Telephone sets including mobile or cellular phones and satellite phone

Institutional reliefs: All imports for the President, diplomatic missions, technical assistance schemes with agreements, and emergency relief

Source: Adapted from "VAT exemptions" by Ghana Revenue Authority (2015). Retrieved from https://gra.gov.gh/index.php/ charging-vat/ 


\section{Appendix 2: Trends in Key Variables}

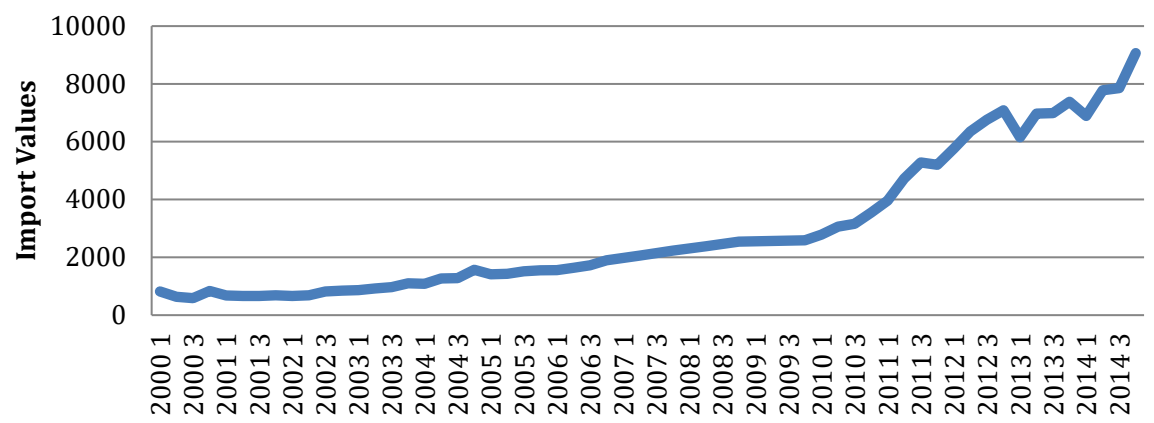

Figure A1. Trends in Imports (Millions of GhC)

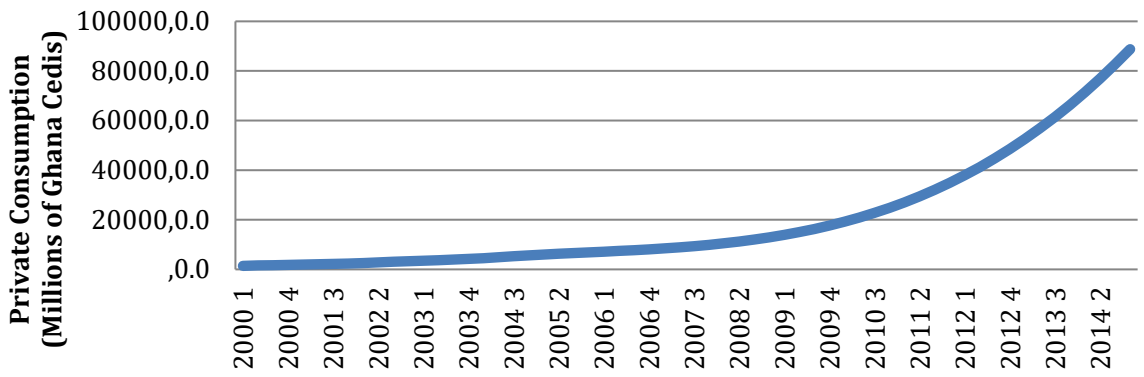

Figure A2. Private Consumption from 2000 to 2014 


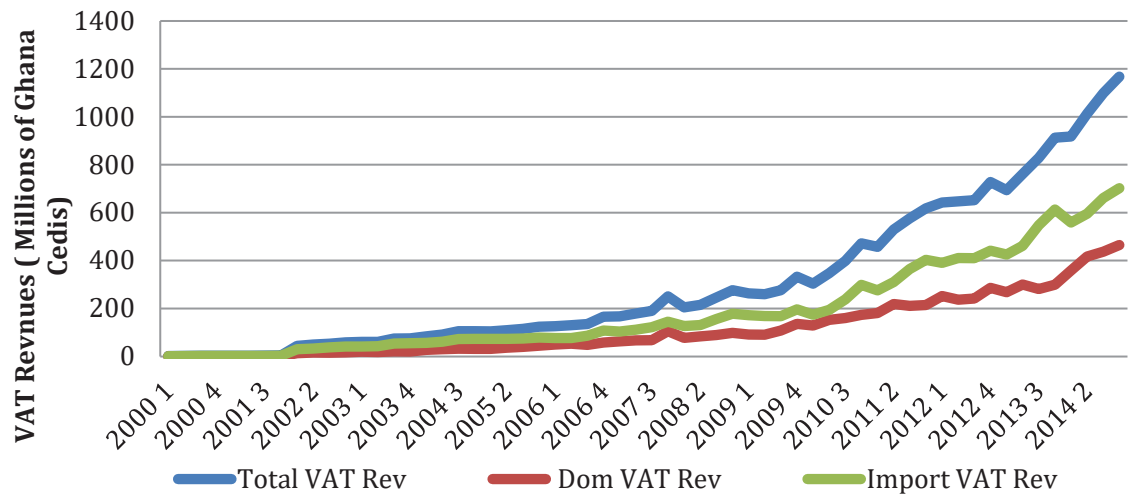

Figure A3. Trends in Total, Import and Domestic VAT Revenues from 2001 to 2014 
